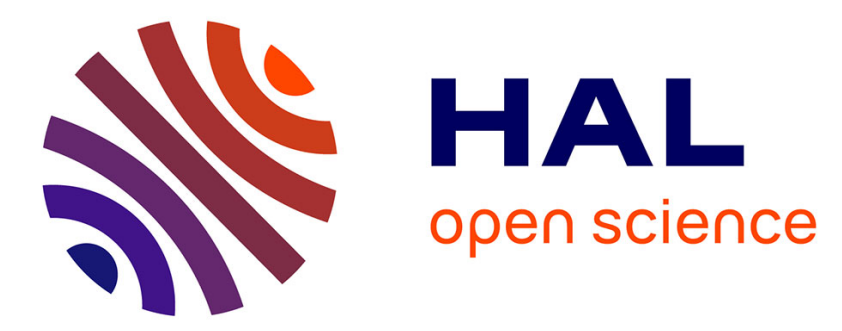

\title{
Effect of the nature of dietary fibre on transit time and faecal excretion in the growing pig
}

Christine Cherbut, J.L. Barry, Monique Wyers, J. Delort-Laval

\section{To cite this version:}

Christine Cherbut, J.L. Barry, Monique Wyers, J. Delort-Laval. Effect of the nature of dietary fibre on transit time and faecal excretion in the growing pig. Animal Feed Science and Technology, 1988, 20 (4), pp.327-333. hal-02720333

\section{HAL Id: hal-02720333 \\ https://hal.inrae.fr/hal-02720333}

Submitted on 1 Jun 2020

HAL is a multi-disciplinary open access archive for the deposit and dissemination of scientific research documents, whether they are published or not. The documents may come from teaching and research institutions in France or abroad, or from public or private research centers.
L'archive ouverte pluridisciplinaire HAL, est destinée au dépôt et à la diffusion de documents scientifiques de niveau recherche, publiés ou non, émanant des établissements d'enseignement et de recherche français ou étrangers, des laboratoires publics ou privés. 


\title{
Short Communication
}

\section{Effect of the Nature of Dietary Fibre on Transit Time and Faecal Excretion in the Growing Pig}

\author{
C. CHERBUT ${ }^{1}$, J.L. BARRY ${ }^{1}$, M. WYERS ${ }^{2}$ and J. DELORT-LAVAL ${ }^{1}$ \\ ${ }^{1}$ Institut National de la Recherche Agronomique, Laboratoire de Technologie des Aliments des \\ Animaux, Rue de la Géraudière, 44072 Nantes Cedex 03 (France) \\ ${ }^{2}$ Ecole Nationale Vétérinaire, Laboratoire d'Histologie-Anatomie Pathologie, Route de Gachet, \\ 44026 Nantes Cedex (France)
}

(Received 20 October 1986; accepted for publication 30 December 1987)

\begin{abstract}
Cherbut, C., Barry, J.L., Wyers, M. and Delort-Laval, J., 1988. Effect of the nature of dietary fibre on transit time and faecal excretion in the growing pig. Anim. Feed Sci. Technol., 20: 327-333.

When added to a fibre-free diet, polyethylene, a substance not modified in the digestive tract and devoid of water-holding capacity, reduces mean transit time (MTT) in the gut of the growing pig from 101.3 to $88.8 \mathrm{~h}$ and increases faecal water excretion from 2 to $43 \mathrm{~g}$ day ${ }^{-1}$. It does not modify the digestibility of the other components of the diet.

However, with the same amount of added wheat bran, more pronounced effects (MTT: $75.7 \mathrm{~h}$; daily faecal water output: $119 \mathrm{~g}$ ) are observed. The mechanical properties of indigestible material, therefore, only partly explain its effect on transit time and faecal excretion in the pig.
\end{abstract}

\section{INTRODUCTION}

Dietary fibre may be defined as the dietary fraction not digested by endogenous enzymes of the digestive tract (Trowell, 1972). It plays a key role in digestive physiology and particularly in the regulation of gastrointestinal transit time: a low fibre diet decreases intestinal motor function (Ruckebusch, 1981) and, conversely, fibre addition contributes to restoring a normal transit time (Canguilhem and Labie, 1977).

From digestibility experiments with ileo-caecal cannulated pigs, Just (1982) concludes that an increasing dietary fibre content results in a higher proportion of digestible nutrients disappearing in the large intestine. At high levels of inclusion, pure cellulose or vermiculite added to fibre-free diets tend to reduce transit time and to increase faecal excretion of energy, protein and water (Henry and Etienne, 1969). However, the way in which dietary fibre acts is not fully understood. One of the most recent hypotheses involves a mechanical effect (Bardon and Fioramonti, 1983) which could explain why coarse bran is 
more effective than fine bran in accelerating the passage of digesta (Kirwan et al., 1974; Heller, 1980). Nevertheless, the primary importance of this effect over other dietary fibre properties supposed to be effective, such as pancreatic enzyme activity in the gut (Schneeman, 1982), water-holding capacity (Eastwood et al., 1983) or ability to generate fermentation end-products (Hellendoorn, 1978), is not well established.

Difficulties in determining the main property involved in transit time regulation come from the coexistence of several characteristics of the indigestible fraction, such as particle size, water-holding capacity (Kirwan et al., 1974) or fermentability. The aim of the present experiment was to evaluate the influence of an organic diluent, polyethylene (PE), devoid of water-holding capacity and chemically inert, on transit time and faecal excretion. The effect of this supplement, added to a fibre-free diet, was measured in balance and transit time studies on growing pigs and compared to wheat bran, a common source of dietary fibre in one-stomach animals and man.

\section{MATERIALS AND METHODS}

\section{Animals and diets}

Eight castrated male Large White pigs, $\sim 3$ months old and with a mean initial bodyweight of $30 \mathrm{~kg}$ were used. They were housed in metabolism crates at constant temperature $\left(18-20^{\circ} \mathrm{C}\right)$ and light $\left(14 \mathrm{~h} \mathrm{day}^{-1}\right)$ throughout the experiment.

The basal diet fed throughout the experiment was a commercial milk replacer consisting mainly of skim milk powder enriched with animal fat, dried whey, starch, minerals and vitamins. It contained $<0.5 \%$ neutral detergent fibre (Goering and van Soest, 1970). The source of indigestible material was either commercial wheat bran as a source of fibre or PE as an inert product. Both supplements were ground in a hammermill, then passed through a 1.6mm sieve. The finer fractions, passed through a 1-mm screen, were discarded.

A marker added to the control and experimental diets consisted of 30 small flexible discs of coloured polyethylene, $\sim 3 \mathrm{~mm}$ in diameter and $0.3-0.5 \mathrm{~mm}$ thick. Their colours were different in order to distinguish the marker added on the same day to the morning and evening meals.

\section{Experimental design and procedures}

Animals were weighed once a week and fed twice daily with the basal diet in a wet form at a level of $1 \%$ of their liveweight. They had free access to water.

The experimental design consisted of two 14-day experimental periods, each preceded by 7 days of adaptation to the experimental diet. During the first experimental period, all the animals were fed the basal diet alone. During the 
second period, they received the same basal diet and a supplement of $100 \mathrm{~g}$ day $^{-1}$ of either bran or PE. Faecal excretion and transit time were measured on all the animals during each experimental period.

For transit time determination, markers were added to the morning and evening meal of the first day of each experimental week. Faeces were collected at 8.00 a.m., 1 and 6 p.m. during the next 6 days.

\section{Preparation and analysis of samples}

Aliquot samples of feeds and faeces were dried and pooled for each animal and each experimental week. They were analysed for dry matter (DM), nitrogen $(\mathrm{N})$ and neutral detergent fibre (NDF). PE particle content was obtained by centrifugation of an aliquot of the pooled dry faeces dispersed in distilled water.

Coloured markers were taken by hand from each dried sample of faeces collected during the experiment. The mean transit time (MTT) was calculated for each single dose, according to Cummings et al. (1976) as follows:

$\mathrm{MTT}=\frac{\sum_{1}^{n} x_{\mathrm{i}} t_{\mathrm{i}}}{\sum_{1}^{n} x_{\mathrm{i}}}$

where $x_{\mathrm{i}}$ is the number of coloured particles present in the stool passed after the time interval $t_{\mathrm{i}}$. Comparisons of feed intake, faecal excretion and mean retention time of the marker were analysed using the Student's $t$-test and variance analysis.

\section{RESULTS AND DISCUSSION}

\section{Digestive balance}

Average intakes of DM, N and fibre are given in Table 1.

On the basal diet, pigs were highly constipated. This constipation was characterized by quite a low $(5.3 \%)$ water content in the faeces, compared to the $25-40 \%$ figures usually found with more conventional diets. A decrease in the frequency of defaecation was also observed in the 8 animals. However, 2 pigs had an abnormally high faecal excretion during the first period, even after 7 days of adaptation to the basal diet. Their main component, lactose or more probably fibre residues from the pre-experimental period, were not analysed. The corresponding data are not included in the calculations.

During the second experimental period, the moisture content of the faeces was significantly higher $(64.9 \%)$ with the bran diet than with the PE diet (24.8\%). Several authors (Stephen and Cummings, 1979; Eastwood et al., 1983) explain the increase in faecal water excretion by the water-holding capacity of 
TABLE 1

Average daily feed intake ( $\mathrm{g}$ per animal)

\begin{tabular}{lllll}
\hline & $n$ & $\begin{array}{l}\text { Dry } \\
\text { matter }\end{array}$ & Nitrogen & $\begin{array}{l}\text { Neutral detergent } \\
\text { fibre }\end{array}$ \\
\hline $\begin{array}{l}\text { Period 1 } \\
\text { Basal diet }\end{array}$ & 6 & $558 \pm 0.6$ & $20.7 \pm 0.02$ & $<3$ \\
$\begin{array}{l}\text { Period 2 } \\
\text { Basal diet } \\
\quad+\text { PE }\end{array}$ & 4 & $803 \pm 18$ & $26.2 \pm 0.6$ & $98.9 \pm 0.1$ \\
$\begin{array}{l}\text { Basal diet } \\
\text { +bran }\end{array}$ & 4 & $790 \pm 17$ & $28.3 \pm 0.7$ & $44.3 \pm 0.1$ \\
\hline
\end{tabular}

TABLE 2

Faecal excretion of dry matter, nitrogen and neutral detergent fibre in pigs fed highly digestible diets either alone (Period 1) or supplemented with polyethylene or bran (Period 2)

\begin{tabular}{|c|c|c|c|c|c|c|c|}
\hline & \multirow{2}{*}{$\begin{array}{l}\text { Water } \\
(\mathrm{g} \\
\left.\text { day }^{-1}\right)\end{array}$} & \multicolumn{2}{|c|}{ Dry matter } & \multicolumn{2}{|l|}{ Nitrogen } & \multicolumn{2}{|c|}{ Neutral detergent fibre } \\
\hline & & g day $^{-1}$ & $\%$ intake & $\mathrm{g} \mathrm{day}^{-1}$ & $\%$ intake & $\mathrm{g} \mathrm{day}^{-1}$ & $\%$ intake \\
\hline \multicolumn{8}{|l|}{ Period 1} \\
\hline Basal diet & 2 & 34.4 & 6.2 & 1.05 & 5.1 & $<1$ & - \\
\hline \multicolumn{8}{|l|}{ Period 2} \\
\hline Basal diet & & & & & & & \\
\hline$+\mathrm{PE}$ & 43 & 128.8 & 16.1 & 1.11 & 4.3 & 91.9 & 92.9 \\
\hline $\begin{array}{l}\text { Basal diet } \\
+ \text { bran }\end{array}$ & 119 & 64.7 & 8.2 & 1.48 & 5.3 & 27.1 & 61.2 \\
\hline
\end{tabular}

the fibre. This explanation does not hold for PE which is devoid of waterholding capacity.

Despite a higher protein intake during the second experimental period, faecal nitrogen excretion remains constant with the $\mathrm{PE}$ diet (Table 2). On the contrary, faecal nitrogen excretion is increased with the bran diet. The observed difference between the data of the first (control) and second (experimental) periods is fully explained by the higher intake of the basal diet $(+15 \%$ DM) and by the low digestibility of the bran protein.

Addition of fibre or PE to the basal diet increases the relative DM faecal excretion (Table 2). Recovery of PE particles is not complete over the 6 days of faeces total collection, but the measured loss does not correspond to a significant disappearance. In contrast, bran NDF shows a 38.8\% disappearance. This figure tends to be lower than those previously reported by Ehle et al. 
(1982) and Stanogias and Pearce (1985). It could be due to the fact that younger animals were used. The increase in DM faecal excretion is fully explained by the amount of fibre in the faeces: addition of fibre to the diet, at the level used in the present experiment, does not change the apparent digestibility of the non-fibrous constituents of the diet. This conclusion does not agree with those of Kass et al. (1980) and Stanogias and Pearce (1985), who explain the decrease in apparent digestibility of the non-fibre fraction of a more conventional diet by an increase either of the rate of passage of digesta or of microbial or endogenous faecal excretion.

\section{Retention time measurement}

Post-mortem histological examination of gastrointestinal wall showed no abnormalities; thus, the observed changes in digestive parameters do not seem to have a pathological origin.

Since, for the same diet, there were no statistically significant differences between mean retention time of the morning and evening meals, both sets of figures were distinguished no further. The proportion of coloured discs recovered from the 8 pigs averaged $64 \%$.

The MTT, $101.3 \mathrm{~h}$ (s.d.=22.8; $n=27$ ) with the basal diet, was reduced by the addition of fibre, either with PE ( $m=88.0$ h; s.d. $=14.4 ; n=16)$ or with bran ( $m=75.7 \mathrm{~h}$; s.d. $=21.2 ; n=16$ ). These MTT values and their reduction after the addition of fibre to the diet are in good agreement with previously published results (Canguilhem and Labie, 1977; Fioramonti and Bueno, 1980; Bardon and Fioramonti, 1983); they are longer than those obtained by Henry and Etienne (1969) after the addition of high levels of pure cellulose and/or vermiculite to the diet.

Since PE particles are chemically inert and devoid of water-holding capacity, they reduce the mean retention time only by a mechanical action. This result is reminiscent of the stimulating influence of mechanical factors on rumen motility (Candau, 1973) and confirms the hypothesis of Bardon and Fioramonti (1983) who postulate that dietary fibre could act in a mechanical way on transit time. On the other hand, bran, though added in a lower amount on a total fibre basis, has a larger effect than PE on transit time: characteristics of bran, not found in PE, such as fermentability and water-holding capacity seem to play a part in the regulation of the digestive motor function. Similar observations have been reported with vermiculite versus cellulose in rabbits (Colin et al., 1976) and more recently with kaolin versus cellulose in mice (Goodlad and Wright, 1983). Nevertheless, the role of fermentation end-products, i.e., volatile fatty acids, has been questioned (Bardon and Fioramonti, 1983).

The fact that PE, devoid of water-holding capacity, simultaneously increased water faecal excretion and the rate of passage of digesta in the digestive 
tract, seems to indicate that increased water faecal excretion after addition of fibre to the diet is partly a consequence of an accelerated transit time.

In conclusion, the present experiment shows that when added in limited amount to a fibre-free diet, dietary fibre acts mechanically by decreasing the mean retention time of food in the digestive tract. On the other hand, it clearly shows that increased faecal water output is partly independent of the waterholding capacity of the fibre source.

\section{REFERENCES}

Bardon, T. and Fioramonti, J., 1983. Nature of the effect of bran on digestive transit time in pig. Br. J. Nutr., 50: 685-690.

Candau, M., 1973. Stimulation physico-chimique et développement du rumen. Thèse Doct. D'Etat, Université de Paris VI, 223 pp.

Canguilhem, R. and Labie, C., 1977. Variation de la durée du transit intestinal chez le porc selon la teneur de la ration en cellulose. Rev. Méd. Vét., 128: 1669-1681.

Colin, M., Maire, C., Vaissaire, J. and Renault, L., 1976. Etude expérimentale du remplacement dans les aliments pour lapins de la cellulose par des lests minéraux: sable et vermiculite. Recl. Méd. Vét., 152: 457-465.

Cummings, J.H., Jenkins, D.J.A. and Wiggins, J.S., 1976. Measurement of the mean transit time of dietary residue through the human gut. Gut, 33: 210-218.

Eastwood, M.A., Robertson, J.A., Brydon, W.G. and McDonald, D., 1983. Measurement of water holding properties of fibre and their faecal bulking activity in man. Br. J. Nutr., 50: 539-547.

Ehle, F.R., Jeraci, M., Robertson, J.B. and van Soest, P.J., 1982. The influence of dietary fiber on digestibility, rate of passage and gastrointestinal fermentation in pigs. J. Anim. Sci., 55: 10711081.

Fioramonti, J. and Bueno, L., 1980. Motor activity in the large intestine of the pig related to dietary fibre and retention time. Br. J. Nutr., 43: 155-161.

Goering, H.K. and van Soest, P.J., 1970. Forage fiber analysis (apparatus, reagents, procedures and some applications). ARS, USDA Agric. Handbook, No.: 379.

Goodlad, R.A. and Wright, N.A., 1983. Effects of addition of kaolin or cellulose to an elemental diet on intestinal cell proliferation in the mouse. Br. J. Nutr., 50: 91-98.

Hellendoorn, E.W., 1978. Fermentation as the principal cause of the physiological activity of indigestible food residue. In: G.A. Spiller (Editor), Topics in Dietary Fiber Research. Plenum Press, New York, pp. 127-168.

Heller, S.N., 1980. Dietary fiber: the effect of particle size of wheat bran on colonic function of young adult men. Am. J. Clin. Nutr., 33: 1734-1744.

Henry, Y. and Etienne, M., 1969. Effets nutritionnels de l'incorporation de cellulose purifiée dans le régime du porc en croissance-finition. Ann. Zootech., 18: 337-357.

Just, A., 1982. The influence of crude fibre from cereals on the net energy value of diets for growth in pigs. Livest. Prod. Sci., 9: 569-580.

Kass, M.L., Van Soest, P.J., Pond, W.G., Lewis, B. and McDowell, R.E., 1980. Utilization of dietary fibre from alfalfa by growing swine. I. Apparent digestibility of diet components in specific segments of the gastrointestinal tract. J. Anim. Sci., 50: 175-191.

Kirwan, W.O., Smith, A.N., McConnell, A.A., Mitchell, W.D. and Eastwood, M.A., 1974. Action of different bran preparations on colonic function. Br. Med. J., 4: 187-189.

Ruckebusch, Y., 1981. Motor functions of the intestine. Adv. Vet. Sci. Comp. Med., 25: 345-369.

Schneeman, B., 1982. Activités enzymatiques digestives d'origine pancréatique; réponse à l'ali- 
ment. In: J.P. Laplace, T. Corring and A. Rerat (Editors), Digestive Physiology in the Pig. Les Colloques de l'INRA No. 12, Institut National de la Recherche Agronomique, Paris, pp. 125-132.

Stanogias, G. and Pearce, G.R., 1985. The digestion of fibre by pigs. 1. The effects of amount and type of fibre on apparent digestibility, nitrogen balance and rate of passage. Br. J. Nutr., 53: 513-530.

Stephen, A.M. and Cummings, J.H., 1979. Water-holding by dietary fibre in vivo and its relationship to faecal output in man. Gut, 20: 722-729.

Trowell, H.C., 1972. Crude fibre, dietary fibre and atherosclerosis. Atherosclerosis, 16: 138-139.

Uden, P., Dolwci, P.E. and van Soest, P.J., 1980. Investigation of chromium, cerium and cobalt as markers in digesta. Rate of passage studies. J. Sci. Food Agric., 31: 625 (abstract). 
